\title{
Temperature and light dependence of the VOC emissions of Scots pine
}

\author{
V. Tarvainen ${ }^{1}$, H. Hakola ${ }^{1}$, H. Hellén ${ }^{1}$, J. Bäck ${ }^{2}$, P. Hari ${ }^{2}$, and M. Kulmala ${ }^{3}$ \\ ${ }^{1}$ Finnish Meteorological Institute, Sahaajankatu 20 E, FI-00880 Helsinki, Finland \\ ${ }^{2}$ Department of Forest Ecology, University of Helsinki, Helsinki, Finland \\ ${ }^{3}$ Department of Physical Sciences, University of Helsinki, Helsinki, Finland
}

Received: 10 August 2004 - Published in Atmos. Chem. Phys. Discuss.: 19 October 2004

Revised: 1 March 2005 - Accepted: 3 March 2005 - Published: 22 March 2005

\begin{abstract}
The volatile organic compound (VOC) emission rates of Scots pine (Pinus sylvestris L.) were measured from trees growing in a natural forest environment at two locations in Finland. The observed total VOC emission rates varied between 21 and $874 \mathrm{ng} \mathrm{g}^{-1} \mathrm{~h}^{-1}$ and 268 and $1670 \mathrm{ng} \mathrm{g}^{-1} \mathrm{~h}^{-1}$ in southern and northern Finland, respectively. A clear seasonal cycle was detected with high emission rates in early spring, a decrease of the emissions in late spring and early summer, high emissions again in late summer, and a gradual decrease in autumn.
\end{abstract}

The main emitted compounds were $\Delta^{3}$-carene (southern Finland) and $\alpha$ - and $\beta$-pinene (northern Finland), with approximate relative contributions of $60-70 \%$ and $60-85 \%$ of the total observed monoterpene emission rates, respectively. Sesquiterpene ( $\beta$-caryophyllene) and 2-methyl-3-buten-2-ol (MBO) emissions were initiated in early summer at both sites. The observed MBO emission rates were between 1 and $3.5 \%$ of the total monoterpene emission rates. The sesquiterpene emission rates varied between 2 and 5\% of the total monoterpene emission rates in southern Finland, but were high $(40 \%)$ in northern Finland in spring.

Most of the measured emission rates were found to be well described by the temperature dependent emission algorithm. The calculated standard emission potentials were high in spring and early summer, decreased somewhat in late summer, and were high again towards autumn. The experimental coefficient $\beta$ ranged from 0.025 to 0.19 (average 0.10 ) in southern Finland, with strongest temperature dependence in spring and weakest in late summer. Only the emission rates of 1,8-cineole were found to be both light and temperature dependent.

Correspondence to: V. Tarvainen

(virpi.tarvainen@fmi.fi)

\section{Introduction}

Scots pine (Pinus sylvestris L.) is one of the most common tree species in the boreal forests, and e.g. in Finland its volatile organic compound (VOC) emissions dominate the annual biogenic VOC emissions (Lindfors and Laurila, 2000; Lindfors et al., 2000). The monoterpene emission characteristics of Scots pine have been described in several studies (Janson, 1993; Rinne et al., 1999, 2000; Staudt et al., 2000; Janson et al., 2001; Komenda and Koppmann, 2002). Janson and de Serves (2001) have also measured high acetone emission rates from Scots pine. So far sesquiterpenes have not been detected in the emissions of Scots pine although other boreal tree species, such as Norway spruce (Picea abies L.) and Downy birch (Betula pubescens L.) emit large amounts of sesquiterpenes during summer (Hakola et al., 2000, 2003). 2-methyl-3-buten-2-ol (MBO) has been observed to be a main component in the air in a pine forest in Colorado (Goldan et al., 1993). Harley et al. (1998) have also measured high MBO emission rates from the needles of several pine species but it has not previously been reported in the emissions of Scots pine in boreal forests.

Once emitted, both sesquiterpenes and MBO are very reactive, the sesquiterpenes especially so, with an atmospheric lifetime of only a few minutes so that they can not be measured in ambient air samples (Hakola et al., 2000, 2003). In daytime, the main sink of MBO is assumed to be the reaction with $\mathrm{OH}$ radicals but it also reacts with ozone and nitrate radical, producing acetone, aldehydes, formic acid, and organic, carbonyl and peroxy nitrates (Finlayson-Pitts and Pitts, 2000, and references therein) thus affecting local photochemistry and atmospheric ozone formation. Sesquiterpenes react readily with atmospheric ozone, and they have a high potential to form secondary organic aerosol (Hoffmann et al., 1997; Jaoui et al., 2003). Bonn and Moortgat (2003) suggest that sesquiterpene ozonolysis could be involved in the atmospheric new particle formation observed frequently

(C) 2005 Author(s). This work is licensed under a Creative Commons License. 
in several locations including Hyytiälä, Finland (Mäkelä et al., 1997; Boy and Kulmala, 2002). The new particle formation and growth processes are, however, probably uncoupled (Kulmala et al., 2000), and the oxidation products of the sesquiterpenes are expected to mainly affect the growth of the particles (see, e.g. Kulmala et al., 2004). Sesquiterpenes also affect tropospheric ozone concentrations, by participating in ozone formation when enough nitrogen oxides are present or acting as ozone sink in a very clean environment, where some of the ozone deposition may be attributed to sesquiterpene reactions (Kurpius and Goldstein, 2003). Currently, the sesquiterpene emission rate data of boreal tree species is very limited.

We have measured the VOC emission rates of Scots pine in two locations in Finland. The seasonal development of the emissions was studied over a period of six months. Also the sesquiterpene and MBO emission rates were measured. The light and temperature dependence of the emissions was studied by darkening experiments and by fitting the experimental data to the light and/or temperature dependent emission algorithms commonly used in biogenic emission modelling (Guenther et al., 1993; Guenther, 1997).

\section{Materials and methods}

\subsection{Emission measurements}

The VOC emission rates of Scots pine (Pinus sylvestris L.) were measured in southern Finland in Hyytiälä $\left(61^{\circ} 51^{\prime} \mathrm{N}\right.$, $\left.24^{\circ} 17^{\prime} \mathrm{E}\right)$ and in the Finnish Lapland in Sodankylä $\left(67^{\circ} 22^{\prime} \mathrm{N}\right.$, $26^{\circ} 39^{\prime} \mathrm{E}$ ). In Hyytiälä the measurements were carried out from March to October in 2003. During the QUEST II (Quantification of Aerosol Nucleation in the European Boundary Layer) campaign (24 March to 14 May 2003) the emission rates were measured daily around noon. Several samples were usually taken per measurement session at $30 \mathrm{~min}$ to $2 \mathrm{~h}$ intervals. During three intensive campaign days the measurements were conducted during the whole day. After the campaign the emission rates were measured during 12 days every month until October 2003. We also conducted experiments where the plant was covered from light.

In Hyytiälä the measured tree was growing in a natural forest environment, with an average tree height of $14 \mathrm{~m}$. The samples were collected at a height of about $11 \mathrm{~m}$. The measured branch received direct sunlight only for a couple of hours in a day. Altogether 132 regular samples (no artificial light conditions) were taken during the measurement period. In Sodankylä the VOC emissions of Scots pine were measured in spring and early summer 2002. The measurements were carried out during five days, starting at the end of April and continuing until the beginning of June, with a total of 22 samples. The tree measured in Sodankylä was younger than the one in Hyytiälä, with a height of about $5 \mathrm{~m}$, and it was growing in a sunny forest environment. The same branch was used for the measurements until the tree started to grow new needles, after which a different branch was sampled each time. In Hyytiälä the branch was placed in the cuvette when the measurements started in March and it remained there until May. After that the branch was placed in the cuvette in the evening and the sampling was started the following day. In Sodankylä the branch was placed in the cuvette in the morning and samples were taken around noon. Even though the adaptation period in Sodankylä was shorter than that in Hyytiälä, successive samples showed no decreasing trend in the emission rate that could have been caused by the handling of the branch.

The emission rates were measured using a dynamic flow through technique. The measured branch was enclosed in a Teflon cuvette with a volume of approximately 201 . The cuvette was equipped with inlet and outlet ports and a thermometer. The photosynthetically active photon flux density (PPFD) was measured just above the cuvette. During the measurements in Hyytialä the PPFD varied between 0 and $1800 \mu \mathrm{mol}$ photons $\mathrm{m}^{-2} \mathrm{~s}^{-1}$ and the temperature between -5 and $32^{\circ} \mathrm{C}$, so a wide range of environmental conditions was covered. The flow through the cuvette was about $81 \mathrm{~min}^{-1}$. Ozone was removed from the inlet air using a pack of $\mathrm{MnO}_{2}$-coated copper nets. The samples were collected onto adsorbent tubes simultaneously from both the inlet and outlet ports. The emission rate $(E)$ is determined as the mass of compound per needle dry weight and time according to

$E=\frac{\left(C_{2}-C_{1}\right) F}{m}$.

Here $C_{2}$ is the concentration in the outgoing air, $C_{1}$ is the concentration in the inlet air, and $F$ is the flow rate into the cuvette. The dry weight of the biomass $(m)$ was determined by drying the needles at $75^{\circ} \mathrm{C}$ until consistent weight was achieved.

The samples were collected on adsorbent tubes filled with Tenax-TA and Carbopack-B. The sampling time was 30 $120 \mathrm{~min}$. The samples were stored in a refrigerator for less than a week prior to analysis in the laboratory. The adsorbent tubes were analyzed using a thermodesorption instrument (Perkin-Elmer ATD-400) connected to a gas chromatograph (HP 5890) with HP-1 column (60 m, i.d. $0.25 \mathrm{~mm})$ and a mass-selective detector (HP 5972). Samples were concentrated in the thermodesorption instrument in a cold trap $\left(-30^{\circ} \mathrm{C}\right)$. The analytical system did not allow the separation of myrcene and $\beta$-pinene; their amount was therefore expressed as a sum and quantified as $\beta$-pinene. Quantification was achieved with five-point calibration using liquid standards in methanol solutions. Standard solutions were injected onto adsorbent tubes that were flushed with helium (flow $100 \mathrm{ml} \mathrm{min}^{-1}$ ) for $5 \mathrm{~min}$ in order to remove methanol.

The detection limit for isoprene and MBO was $32 \mathrm{ng} \mathrm{m}^{3}$. The detection limits of the monoterpenes were $11 \mathrm{ng} \mathrm{m}^{3}$ for camphene, $42 \mathrm{ng} \mathrm{m}^{3}$ for $\Delta^{3}$-carene, $84 \mathrm{ng} \mathrm{m}^{3}$ for 1,8 -cineole, $60 \mathrm{ng} \mathrm{m}^{3}$ for limonene, $30 \mathrm{ng} \mathrm{m}^{3}$ for $\alpha$-pinene, $36 \mathrm{ng} \mathrm{m}^{3}$ for 
$\beta$-pinene, $59 \mathrm{ng} \mathrm{m}^{3}$ for sabinene, $29 \mathrm{ng} \mathrm{m}^{3}$ for terpinolene, and $79 \mathrm{ng} \mathrm{m}^{3}$ for $\beta$-caryophyllene. These detection limits correspond to emission rates between 0.6 and $3.3 \mathrm{ng} \mathrm{g}^{-1} \mathrm{~h}^{-1}$ for the monoterpenes and approximately $4.5 \mathrm{ng} \mathrm{g}^{-1} \mathrm{~h}^{-1}$ for 1,8 -cineole and $\beta$-caryophyllene. The error of the emission rate measurements was evaluated by simultaneously measuring two different branches of the same tree. Altogether 40 samples were taken and the measured emission rates were standardized to $303.15 \mathrm{~K}$ and $1000 \mu \mathrm{mol}$ photons $\mathrm{m}^{-2} \mathrm{~s}^{-1}$. The relative standard deviation of the emission rate measurement was about $40 \%$ for the monoterpenes, $50 \%$ for isoprene and $\mathrm{MBO}$, and $60 \%$ for the sesquiterpenes. There were very few unresolved peaks that could be mono- or sesquiterpenes in the chromatograms, thus the likelihood of significant contributions from unidentified species is very small.

\subsection{Emission algorithms}

When modelling the biogenic VOC emissions for e.g. emission inventory purposes or for local photochemistry studies, two mechanisms are generally considered: the temperature controlled volatilization of hydrocarbons from storage pools inside the leaf (Ciccioli et al., 1997; Guenther et al., 1993; Hauff et al., 1999; Lamb et al., 1985; Schuh et al., 1997), and the direct emissions of newly synthesized hydrocarbons, which are under enzymatic control and strongly dependent on leaf temperature and light intensity (e.g. Monson et al., 1995). Monoterpenes are usually described as storage pool emissions, while isoprene is thought to be emitted directly after the synthesis and not stored inside the plant. However, several authors have reported both light and temperature controlled emissions of terpenoids other than isoprene from some plant species, including Sots pine (e.g. Hansen and Seufert, 2003; Shao et al., 2001; Schuh et al., 1997; Staudt et al., 1997; Steinbrecher and Hauff, 1996; Steinbrecher et al., 1999; Seufert et al., 1997; Komenda et al., 1999).

In this work we have calculated the emission potentials of Scots pine in Sodankylä and Hyytiälä by fitting the experimental data to the temperature and light dependent emission algorithms proposed by Guenther et al. (1993) and Guenther (1997). The observed emission rate $(E)$ is parameterised as

$E=\gamma E_{0}$

where $E_{0}$ is the emission rate at standard conditions (303.15 K, $1000 \mu \mathrm{mol}$ photons $\mathrm{m}^{-2} \mathrm{~s}^{-1}$ ), henceforth called the standard emission potential, and $\gamma$ is a non-dimensional environmental correction factor which includes the effects of temperature and light conditions.

For pool emissions the environmental correction factor is (Guenther et al., 1993)

$\gamma_{P}=\exp \left(\beta\left(T-T_{S}\right)\right)$.

Here $T(\mathrm{~K})$ is the leaf temperature and $T_{S}$ is the leaf temperature at standard conditions. $\beta$ is an empirical coefficient, which is usually set at 0.09 (Guenther et al., 1993). In this work, however, we carried out nonlinear regression in order to fit also the $\beta$ coefficient individually for each compound.

The environmental correction factor for the direct emissions of newly synthesized compounds is of the form

$\gamma_{S}=C_{T} C_{L}$

where $C_{T}$ is the temperature correction and $C_{L}$ is the light correction. These are parameterised as (Guenther, 1997)

$$
\begin{aligned}
C_{L} & =\frac{\alpha C_{L 1} L}{\sqrt{1+\alpha^{2} L^{2}}} \\
C_{T} & =\frac{\exp \left(\left[C_{T 1}\left(T-T_{S}\right)\right] / R T_{S} T\right)}{C_{T 3}+\exp \left(\left[C_{T 2}\left(T-T_{M}\right)\right] / R T_{S} T\right)} .
\end{aligned}
$$

Here again $T(\mathrm{~K})$ is the temperature and $T_{S}$ is the standard temperature. $L$ is the photosynthetically active photon flux density (PPFD, $\mu$ mol photons $\mathrm{m}^{-2} \mathrm{~s}^{-1}$ ), $R$ is the universal gas constant, and $C_{L 1}, C_{T 1}, C_{T 2}, C_{T 3}, T_{M}$ and $\alpha$ are empirical constants given by Guenther (1997).

\section{Results and discussion}

\subsection{Observed emissions}

In Finland Scots pine has two genotypes that differ in the emitted monoterpene composition. One genotype mainly emits $\Delta^{3}$-carene while the other does not emit $\Delta^{3}$-carene at all (Hiltunen, 1968). The trees measured in the present study turned out to be of different types. The tree growing in Sodankylä emitted no $\Delta^{3}$-carene, and $60-85 \%$ of its emission consisted of $\alpha$ - and $\beta$-pinene and myrcene, whereas the emission of the tree measured in Hyytiälä mainly consisted of $\Delta^{3}$-carene (60-70\%). The average noontime emission rates observed in Sodankylä and Hyytiälä during their respective measurement periods are presented in Fig. 1.

The observed total VOC emission rates were of the same order of magnitude at both locations, varying between 268 and $1670 \mathrm{ng} \mathrm{g}^{-1} \mathrm{~h}^{-1}$ in Sodankylä and between 21 and $874 \mathrm{ng} \mathrm{g}^{-1} \mathrm{~h}^{-1}$ in Hyytiälä. The very low emissions in Hyytiälä in the beginning of April 2003 (Fig. 1, lower panel) are explained by a cold spell with temperatures close to or below zero during the two days. In general, the emissions observed in Sodankylä were higher than those in Hyytiälä. In Hyytiälä, a clear seasonal cycle was detected with high emission rates in early spring, a decrease of the emissions in late spring and early summer, high emissions again in late summer, and a gradual decrease in autumn.

According to the statistics of the Finnish Meteorological Institute the weather conditions during the measurements in 2002 were exceptional, which might partly explain the high emissions observed in Sodankylä. The thermal spring started earlier than normal, especially in the northern parts of the country. In addition, the spring was very warm, with 

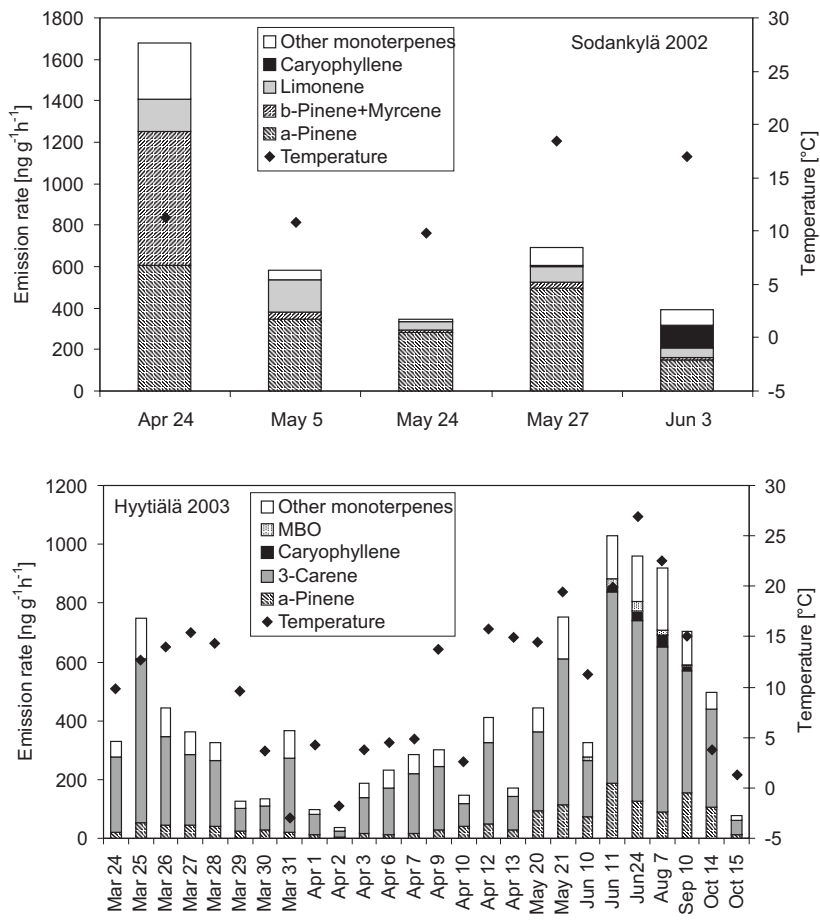

Fig. 1. Average noontime emission rates measured in AprilJune 2002 in Sodankylä and in March-October 2003 in Hyytiälä. Other monoterpenes comprises camphene, sabinene, 1,8-cineole, linalool, and bornyl acetate in Sodankylä, and camphene, sabinene, $\beta$-pinene+myrcene, terpinolene, limonene, 1,8-cineole, $\beta$-phellandrene, terpinolene, and bornyl acetate in Hyytiälä. The average temperature during the measurements (solid diamonds) is shown on the right hand axis. Note that the $\mathrm{x}$-axis is not in scale because the averages for each measurement day are shown at regular intervals.

record high temperatures in the north, and the growing season started much earlier than normal. In 2003 the spring and early summer were cooler than average in the southern parts of the country, while the temperatures were close to long term averages in August, September and October.

There were also changes in the composition of the emissions during the measurement period. In Sodankylä, the April emissions were dominated by $\alpha$ - and $\beta$-pinene, with approximate relative contributions of $35 \%$ and $40 \%$ of the observed total monoterpene emission rates, respectively. In May and June the contribution of $\beta$-pinene was reduced to the 5\% level, while $\alpha$-pinene remained the most abundant emitted compound (55-80\%) throughout the measurement period. In Hyytiälä, the contribution of $\alpha$-pinene was at the $10 \%$ level in early spring, after which it doubled and stayed around $20 \%$ until October. The contribution of $\Delta^{3}$-carene, on the other hand, was approximately $70 \%$ in March and April, after which it dropped slightly, and was around $60-65 \%$ during the rest of the measurement period.

In early summer, sesquiterpene ( $\beta$-caryophyllene) and 2methyl-3-buten-2-ol (MBO) emissions were detected at both sites, although the emission rates were very low. In Sodankylä the MBO emission rates were approximately $1-2 \%$ of the total monoterpene emission rates, and in Hyytiälä, they stayed between $2-3.5 \%$ of the total monoterpene emissions from the onset of the emissions until the cessation in September. The observed $\beta$-caryophyllene emission rates, on the other hand, were about $40 \%$ and $2 \%$ of the observed total monoterpene emission rates in June in Sodankylä and Hyytialä, respectively. Later in summer the $\beta$-caryophyllene emissions in Hyytiälä were slightly higher, reaching approximately $5 \%$ of the observed total monoterpene emissions in August. The sesquiterpene emissions in Hyytiälä also ceased in September. In addition to $\beta$-caryophyllene also some other unidentified sesquiterpenes were detected. In Sodankylä the other sesquiterpenes are tentatively identified as longifolene and elemene according to the NIST mass spectra library. These other sesquiterpenes were emitted at about the same rate as $\beta$-caryophyllene in May, but their emission rates did not increase in June like the emission rates of $\beta$ caryophyllene. Also in Hyytiälä other sesquiterpenes than $\beta$-caryophyllene were detected, tentatively identified as $\alpha$ farnesene and $\alpha$-caryophyllene. However, at both sites $\beta$ caryophyllene was the dominant sesquiterpene.

\subsection{Light dependence of emissions}

To study the light dependence of the monoterpene emissions of Scots pine we conducted experiments in which the measured branch was covered from light and samples were collected from the darkened cuvette. The experiment presented here was started at 7 a.m. on 7 August. Hourly emission samples were first collected from the selected branch under normal light conditions during the day. The cuvette was covered from light at $6.30 \mathrm{p} . \mathrm{m}$. and sampling was continued throughout the night and for several hours after the removal of the cover at 7 a.m. on 8 August.

The emissions measured during the experiment are shown in Fig. 2 together with the temperature in the cuvette. The emission rates of all monoterpenes had already decreased from the high midday values when the cuvette was darkened and after recovering from an initial drop in the emissions they continued to do so also in the complete darkness, in harmony with the decreasing temperature (Fig. 2, upper panel, temperature in lower panel). The emissions of MBO and 1,8-cineole, however, disappeared almost completely when the cuvette was darkened, while the $\beta$-caryophyllene emission rates stayed at the approximate average level of the rates measured when the cuvette was receiving light (Fig. 2, lower panel). After the cover was removed, both the MBO and $\beta$ caryophyllene emission rates rapidly increased to quite high values for a few hours before adjusting approximately to the level of the previous day. The 1,8-cineole emission rates also recovered after the cover was removed, but there was no sudden emission burst. The MBO emissions increased immediately after removing the cover, whereas the $\beta$-caryophyllene 
Table 1. Standardized $\left(30^{\circ} \mathrm{C}\right)$ seasonal emissions in Hyytiälä in 2003. The standard emission potentials $E_{0}\left(\mathrm{ng} \mathrm{g}^{-1} \mathrm{~h}^{-1}\right)$ and the empirical $\beta$ coefficients were obtained by a nonlinear regression fit of the data to the pool algorithm of Guenther et al. (1993) (Eq. 3). The standard error of the estimate is given in parenthesis. $\mathrm{R}$ squared and the number of observations $(\mathrm{N})$ are also given for each case. N/A indicates that the regression either did not converge or was inconclusive.

\begin{tabular}{|c|c|c|c|}
\hline SPRING & $\boldsymbol{E}_{0}$ & $\beta$ & $\mathbf{R}^{2}(\mathbf{N})$ \\
\hline Camphene & $39(13)$ & 0.0926 & $0.47(44)$ \\
\hline$\Delta^{3}$-Carene & $1642(850)$ & 0.1042 & $0.33(44)$ \\
\hline Limonene & $13(7)$ & 0.0572 & $0.12(36)$ \\
\hline$\beta$-Phellandrene & $98(57)$ & 0.0707 & $0.16(44)$ \\
\hline$\alpha$-Pinene & $196(57)$ & 0.0981 & $0.56(44)$ \\
\hline$\beta$-Pinene & $52(25)$ & 0.0824 & $0.26(44)$ \\
\hline Sabinene & $74(36)$ & 0.1031 & $0.34(44)$ \\
\hline Terpinolene & 44 (19) & 0.0810 & $0.33(39)$ \\
\hline Total monoterpenes & $2144(1005)$ & 0.0994 & $0.35(44)$ \\
\hline MBO & Not observed & - & - \\
\hline$\beta$-Caryophyllene & Not observed & - & - \\
\hline EARLY SUMMER & $\boldsymbol{E}_{0}$ & $\beta$ & $\mathbf{R}^{2}(\mathbf{N})$ \\
\hline Camphene & $103(16)$ & 0.1167 & $0.66(35)$ \\
\hline$\Delta^{3}$-Carene & $4010(556)$ & 0.1931 & $0.85(35)$ \\
\hline Limonene & $33(16)$ & 0.1056 & $0.16(27)$ \\
\hline$\beta$-Phellandrene & $71(32)$ & 0.0907 & $0.26(26)$ \\
\hline$\alpha$-Pinene & 677 (108) & 0.1374 & $0.72(35)$ \\
\hline$\beta$-Pinene & $158(24)$ & 0.1612 & $0.78(35)$ \\
\hline Sabinene & $130(22)$ & 0.1731 & $0.80(29)$ \\
\hline Terpinolene & $66(16)$ & 0.1446 & $0.70(22)$ \\
\hline Total monoterpenes & $5184(733)$ & 0.1759 & $0.83(35)$ \\
\hline MBO & $92(19)$ & 0.1349 & $0.82(12)$ \\
\hline$\beta$-Caryophyllene & $160(160)$ & 0.1855 & $0.60(4)$ \\
\hline LATE SUMMER & $\boldsymbol{E}_{0}$ & $\beta$ & $\mathbf{R}^{2}(\mathbf{N})$ \\
\hline Camphene & $37(2)$ & 0.0780 & $0.76(29)$ \\
\hline$\Delta^{3}$-Carene & $696(56)$ & 0.0981 & $0.66(29)$ \\
\hline Limonene & $14(1)$ & 0.0904 & $0.66(21)$ \\
\hline$\beta$-Phellandrene & $29(3)$ & 0.0248 & $0.08(28)$ \\
\hline$\alpha$-Pinene & $130(6)$ & 0.0819 & $0.77(29)$ \\
\hline$\beta$-Pinene & $44(2)$ & 0.0786 & $0.72(29)$ \\
\hline Sabinene & $36(3)$ & 0.0760 & $0.53(27)$ \\
\hline Terpinolene & $20(2)$ & 0.0352 & $0.19(27)$ \\
\hline Total monoterpenes & $1015(52)$ & 0.0824 & $0.72(29)$ \\
\hline MBO & $28(1)$ & 0.0763 & $0.83(24)$ \\
\hline$\beta$-Caryophyllene & N/A & - & - \\
\hline AUTUMN & $E_{0}$ & $\beta$ & $\mathbf{R}^{2}(\mathbf{N})$ \\
\hline Camphene & $135(55)$ & 0.1151 & $0.70(21)$ \\
\hline$\Delta^{3}$-Carene & 3836 (2616) & 0.1483 & $0.61(23)$ \\
\hline Limonene & $16(3)$ & 0.0374 & $0.68(9)$ \\
\hline$\beta$-Phellandrene & N/A & - & - \\
\hline$\alpha$-Pinene & $869(462)$ & 0.1126 & $0.56(23)$ \\
\hline$\beta$-Pinene & $108(50)$ & 0.1014 & $0.55(24)$ \\
\hline Sabinene & $33(18)$ & 0.0615 & $0.27(17)$ \\
\hline Terpinolene & $70(42)$ & 0.0798 & $0.31(20)$ \\
\hline Total monoterpenes & 3428 (1612) & 0.1074 & $0.58(24)$ \\
\hline MBO & N/A & - & - \\
\hline$\beta$-Caryophyllene & $158(295)$ & 0.1606 & $0.16(8)$ \\
\hline
\end{tabular}

emissions started to increase about an hour later together with the 1,8-cineole emissions.

The behaviour of the monoterpenes after the darkening of the cuvette is in agreement with that described by Niinemets and Reichstein (2003) as typical for highly volatile compounds whose emissions are not under stomatal control. The
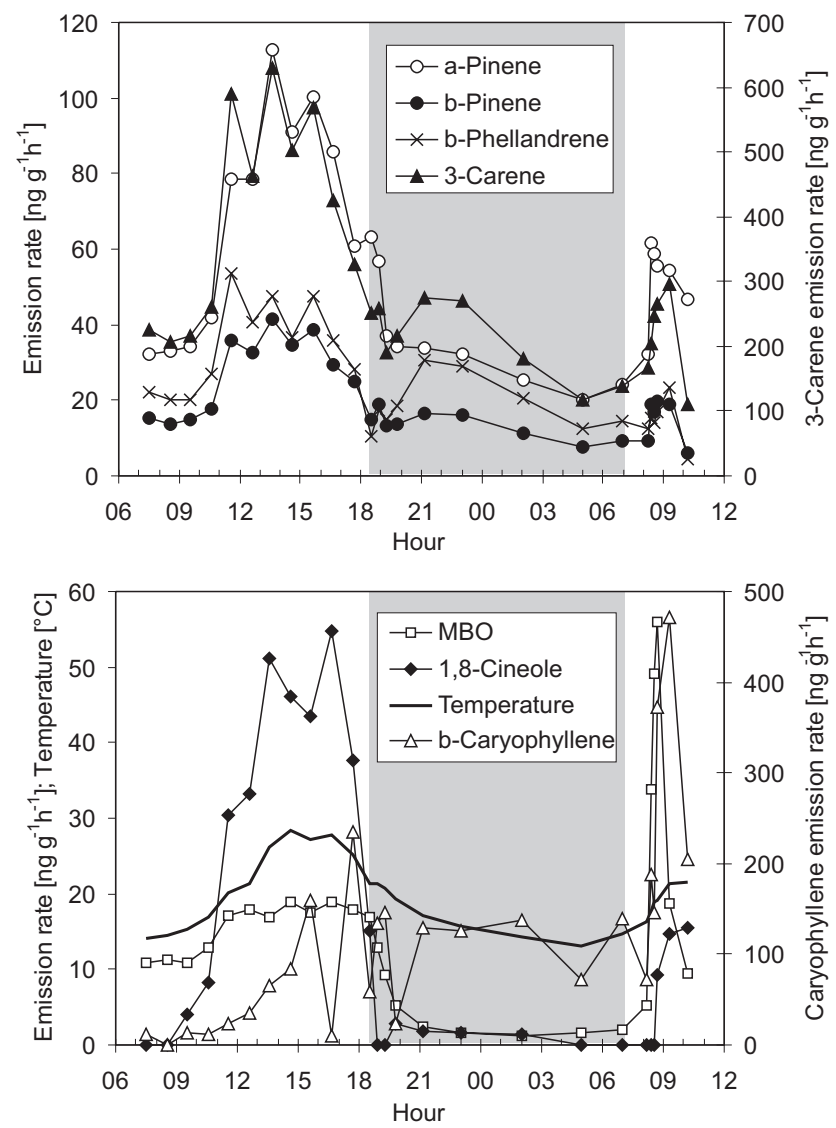

Fig. 2. Variation of the VOC emission rates of Scots pine and the temperature in Hyytiälä during the darkening experiment on 7-8 August 2003. The branch was covered from light at 6:30 p.m. on the 7 th and the cover was removed at 7:00 a.m. on the 8th.

analysis of Niinemets and Reichstein (2003) further predicts bursts of emission after stomatal opening for more water soluble compounds, such as MBO. The results of this experiment further suggest that $\mathrm{MBO}$ emission rates may be dependent on the light intensity as well as the temperature, as proposed by Harley et al. (1998). This could also be true for 1,8-cineole which showed zero emissions at the end of the darkening period.

\subsection{Calculated emissions}

\subsubsection{Standard emission potentials}

The existence of light and temperature dependencies of the measured emission rates was further studied and the standard emission potentials were calculated using emission modelling techniques. In this analysis the measured emission rates were fitted to both the temperature dependent pool algorithm (Eq. 3) and the combined light and temperature dependent algorithm (Eq. 4) using nonlinear regression. Since not only the emission rates but also the spectrum of the emitted 

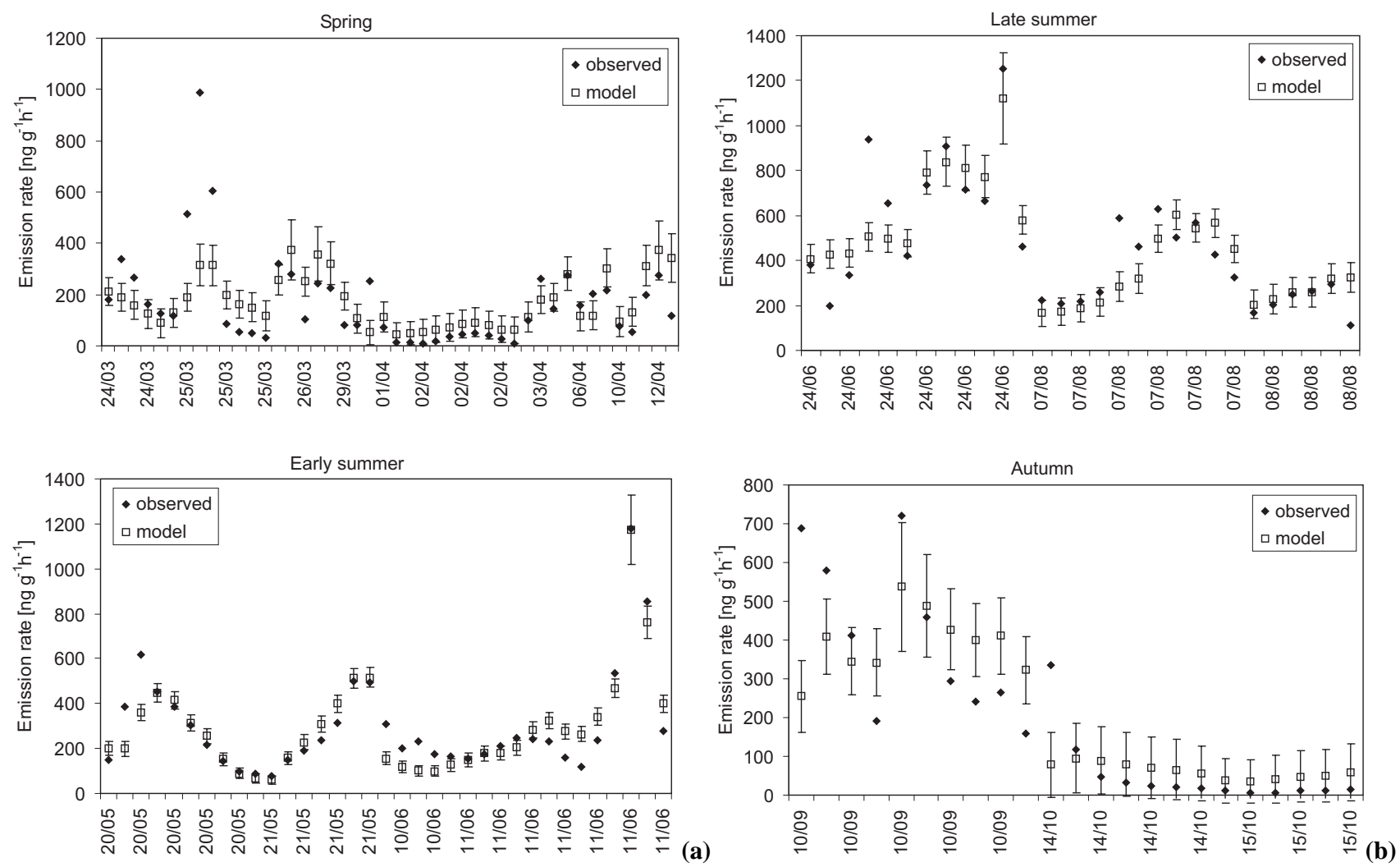

Fig. 3. (a) Measured and modelled $\Delta^{3}$-carene emissions in Hyytiälä in spring and early summer in 2003. Note that the $x$-axis is not in scale because each measurement is shown using regular intervals. The error bars indicate the $95 \%$ confidence limits of the nonlinear regression fit. (b) Same as (a) but for late summer and autumn in 2003 .

compounds showed significant variation during the measurement period, the data from Hyytiälä was divided into seasonal data sets according to the average thermal seasons. In the southern parts of Finland thermal spring (defined as the period with the smoothed daily average temperature between 0 and $10^{\circ} \mathrm{C}$ ) usually starts in late March and lasts until early May, while thermal summer (daily average temperature above $10^{\circ} \mathrm{C}$ ) extends from mid-May to September, according to the statistics of the Finnish Meteorological Institute. In this analysis the summer period was further divided into early (20 May through 11 June) and late (24 June through 8 August) summer. The rest of the measurements (9 September through 15 October) were considered to represent autumn. The data from Sodankylä, on the other hand, was so sparse and scattered that no seasonal grouping was possible, and thus each month was treated separately.

Most of the measured emission rates were well described by the temperature dependent pool algorithm (Eq. 3), whereas the combined temperature and light algorithm (Eq. 4) generally performed poorly in the nonlinear regression analysis. The standard emission potentials obtained by fitting the temperature algorithm to the spring, early summer, late summer, and autumn data from Hyytiälä, with the corresponding $\beta$ coefficient values and the nonlinear regres- sion statistics are given in Table 1. The standard emission potentials obtained by fitting the temperature algorithm to the April, May and June data from Sodankylä with the $\beta$ coefficient values and regression statistics are given in Table 2. Only nonzero measured emission rates were included in the analysis. Also cases where the regression statistics are poor are shown in order to facilitate an evaluation of the performance of the algorithm during different seasons and with different compounds.

In general it can be said that for most of the modelled monoterpenes, the standardized emission potentials were high in spring and especially early summer, decreased somewhat in late summer, and were high again towards autumn. This type of seasonal behaviour with higher spring emission potentials has also been observed elsewhere (Janson, 1993; Komenda and Koppmann, 2002).

In Hyytiälä the $\beta$ coefficient values obtained for the different compounds ranged from 0.025 to 0.19 , with an average of 0.10 (Table 1). The average value is close to the empirical value 0.09 which is usually assigned to the coefficient in biogenic emission modelling studies (Guenther et al., 1993; Guenther, 1997). The highest coefficient values, indicating the strongest temperature dependence, were obtained in early summer (average 0.15), while the dependence was weakest 
in late summer (average 0.07). In Sodankylä the coefficient values were between 0.036 and 0.56 , with an average of 0.14 (Table 2).

\subsubsection{Applicability of the algorithms}

According to the results, the temperature algorithm was not as successful in describing the spring emissions as those during the other seasons in Hyytiälä. In Sodankylä there are so few data that one should be very careful in evaluating the applicability of the algorithm based on this analysis, but also there the performance of the algorithm improves towards summer. It is quite probable, in fact, that in addition to temperature there are other processes during the spring recovery period of vegetation, perhaps related to the plant developmental stage or the environmental conditions (e.g. strong irradiance in connection with rather low temperatures and low water availability), which also affect the emission patterns (Bäck et al., in preparation, $2005^{1}$ ).

In addition to the general tendency of poor spring performance, there are also differences related to the different compounds. For example in Hyytiälä limonene is extremely poorly described in spring and early summer while the algorithm performs reasonably well in predicting limonene emissions in late summer and autumn. $\beta$-phellandrene, on the other hand does not seem to be captured by the algorithm at all, and its performance with sabinene and terpinolene becomes poorer as the summer progresses. However, these compounds are only minor constituents of the total monoterpene emission and their emission data are therefore more uncertain, bringing an added uncertainty also to the nonlinear regression analysis.

Harley et al. (1998) have reported high emission rates of MBO from several pine species. They also found that these emissions were both temperature and light dependent, whereas in this study the MBO emissions appear to be well described by the temperature dependent pool algorithm $\left(\mathrm{R}^{2}\right.$ between 0.78 and 0.98). Fitting the measured MBO data to the combined temperature and light dependent algorithm (Eq. 4) resulted in a very poor agreement $\left(\mathrm{R}^{2}\right.$ below 0.10$)$. Harley et al. (1998) have pointed out that quantitative analysis of MBO presents several challenges. Although the standard solution behaved well in the analysis, we cannot totally rule out the possibility of dehydration of MBO in real samples since small amounts of isoprene were also detected.

The 1,8-cineole emissions measured in Hyytiälä in 2003, on the other hand, were well described by the light and temperature dependent algorithm (Eq. 4), yielding a standard emission potential of $68 \pm 4 \mathrm{ng} \mathrm{g}^{-1} \mathrm{~h}^{-1}$ over the whole measurement period ( $\mathrm{R}^{2}$ of $0.84 ; 14$ observations). The pool algorithm (Eq. 3) performed almost equally well, with a standard emission potential of $68 \pm 8 \mathrm{ng} \mathrm{g}^{-1} \mathrm{~h}^{-1}$ and $\beta$ coefficient

${ }^{1}$ Bäck, J., Hari, P., Hakola, H., Juurola, E., and Kulmala, M.: Dynamics of monoterpene emissions on Pinus sylvestris during early spring, in preparation, 2005.
Table 2. Standardized $\left(30^{\circ} \mathrm{C}\right)$ emissions in Sodankylä in 2002. The standard emission potentials $E_{0}\left(\mathrm{ng} \mathrm{g}^{-1} \mathrm{~h}^{-1}\right)$ and the empirical $\beta$ coefficients were obtained by a nonlinear regression fit of the data to the pool algorithm of Guenther et al. (1993) (Eq. 3). The standard error of the estimate is given in parenthesis. R squared and the number of observations $(\mathrm{N})$ are also given for each case. N/A indicates that the regression either did not converge or was inconclusive.

\begin{tabular}{|c|c|c|c|}
\hline 24 APRIL & $\boldsymbol{E}_{0}$ & $\beta$ & $\mathbf{R}^{2}(\mathbf{N})$ \\
\hline Camphene & $46(122)$ & 0.0613 & $0.28(6)$ \\
\hline Limonene & $1473(8842)$ & 0.1279 & $0.25(6)$ \\
\hline$\alpha$-Pinene & $4051(27600)$ & 0.1080 & $0.07(6)$ \\
\hline$\beta$-Pinene+Myrcene & $6559(89893)$ & 0.1321 & $0.06(6)$ \\
\hline Sabinene & 865 (11584) & 0.1310 & $0.06(6)$ \\
\hline Total monoterpenes & $14951(94704)$ & 0.1295 & $0.06(6)$ \\
\hline $\mathrm{MBO}$ & Not observed & - & - \\
\hline$\beta$-Caryophyllene & Not observed & - & - \\
\hline MAY (average) & $\boldsymbol{E}_{0}$ & $\beta$ & $\mathbf{R}^{2}(\mathbf{N})$ \\
\hline Camphene & $115(42)$ & 0.0941 & $0.55(10)$ \\
\hline Limonene & N/A & - & - \\
\hline$\alpha$-Pinene & $1103(658)$ & 0.0548 & $0.13(13)$ \\
\hline$\beta$-Pinene+Myrcene & $60(61)$ & 0.0361 & $0.03(12)$ \\
\hline Sabinene & $1723(2122)$ & 0.5618 & $0.93(13)$ \\
\hline Total monoterpenes & $1677(466)$ & 0.0763 & $0.54(12)$ \\
\hline $\mathrm{MBO}$ & $16(5)$ & 0.1090 & $0.78(7)$ \\
\hline$\beta$-Caryophyllene & $37(5)$ & 0.1453 & $0.99(4)$ \\
\hline 3 JUNE & $\boldsymbol{E}_{0}$ & $\beta$ & $\mathbf{R}^{2}(\mathbf{N})$ \\
\hline Camphene & $53(5)$ & 0.1001 & $0.99(3)$ \\
\hline Limonene & $275(23)$ & 0.1431 & $1.00(3)$ \\
\hline$\alpha$-Pinene & 964 (417) & 0.1480 & $0.94(3)$ \\
\hline$\beta$-Pinene+Myrcene & $160(107)$ & 0.1870 & $0.92(3)$ \\
\hline Sabinene & $48(15)$ & 0.1914 & $0.98(3)$ \\
\hline Total monoterpenes & $1466(522)$ & 0.1473 & $0.96(3)$ \\
\hline $\mathrm{MBO}$ & $61(22)$ & 0.2143 & $0.98(3)$ \\
\hline$\beta$-Caryophyllene & $533(182)$ & 0.1237 & $0.95(3)$ \\
\hline
\end{tabular}

0.1367 ( $\mathrm{R}^{2}$ of 0.83 ). The few 1,8-cineole emission rates measured in Sodankylä in June 2002 were also well described by the temperature and light dependent algorithm (Eq. 4), with a standard emission potential of $246 \pm 27 \mathrm{ng} \mathrm{g}^{-1} \mathrm{~h}^{-1}\left(\mathrm{R}^{2}\right.$ of $0.80 ; 3$ observations). The pool algorithm (Eq. 3 ) yielded a slightly higher emission potential $280 \pm 147 \mathrm{ng} \mathrm{g}^{-1} \mathrm{~h}^{-1}$ and $\beta$ coefficient 0.1557 ( $\mathrm{R}^{2}$ of 0.92$)$. Thus, the regression produced almost identical results, even though in both cases the emission potentials given by the pool algorithm had larger standard deviations. However, in this analysis 1,8-cineole was the only compound with which the light and temperature dependent algorithm performed well, and keeping in mind the results of the darkening experiment, we may tentatively identify Scots pine as a light and temperature dependent 1,8-cineole emitter. However, our data is very limited - 

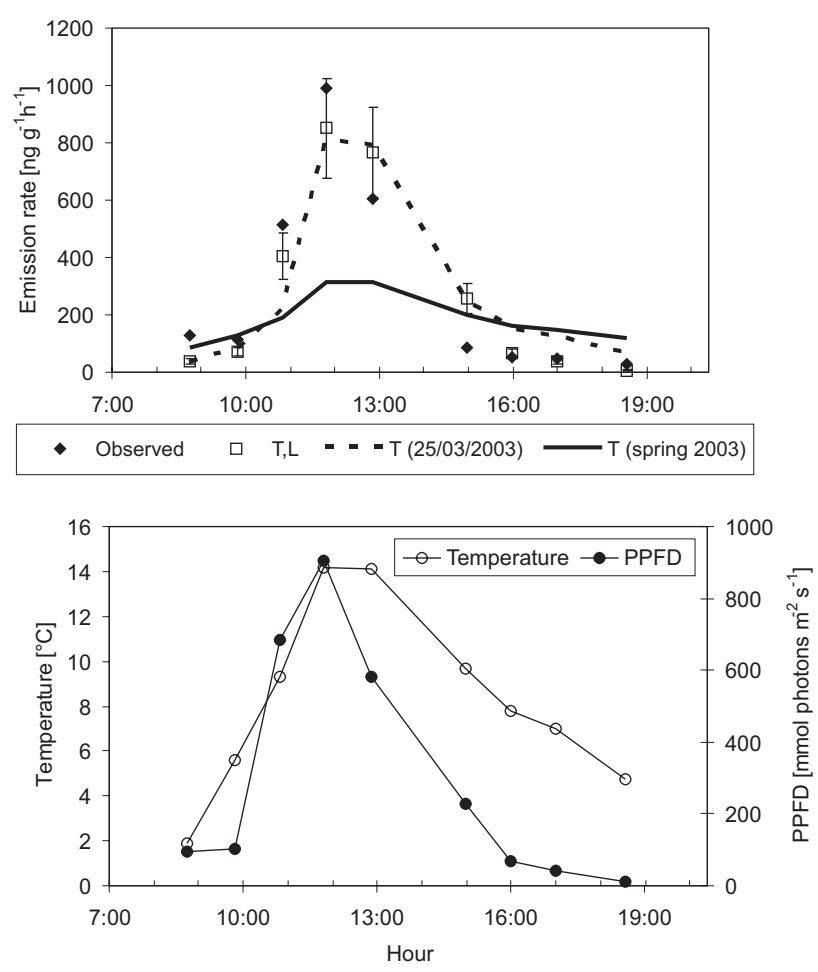

\begin{tabular}{lcrr}
\hline & $\mathbf{E}_{\mathbf{0}}\left[\mathrm{ng} \mathrm{g}^{-1} \mathbf{h}^{-1}\right]$ & & $\mathbf{R}^{\mathbf{2}}$ \\
\hline T,L & $6460(571)$ & - & 0.89 \\
T(25.03.2003) & $50323(65442)$ & 0.2614 & 0.78 \\
T(spring 2003) & $1642(850)$ & 0.0674 & 0.73 \\
\hline
\end{tabular}

Fig. 4. Measured and modelled $\Delta^{3}$-carene emissions in Hyytiälä on 25 March 2003 (upper panel). The light and temperature dependent algorithm (Eq. 4) is denoted by T, L. The temperature algorithm (Eq. 3) is denoted by T. T(25/03/2003) is fitted to the data of 25 March only, while T(spring 2003) refers to the seasonally fitted algorithm (same as in the upper panel of Fig. 3a). The error bars indicate the $95 \%$ confidence limits of the nonlinear regression fit to $\mathrm{T}, \mathrm{L}$. The lower panel shows the temperature and the photosynthetically active radiation (PPFD). The standard emission potentials $\left(30^{\circ} \mathrm{C}\right)$ obtained with the different models are given under the figure, together with the standard error of the estimate (in parenthesis), the $\beta$ coefficient (when applicable) and $\mathrm{R}$ squared.

for example in Hyytiälä cineole was observed in only 14 of the 132 samples, and more measurements are needed, especially in the late summer conditions when the emissions were highest.

In Hyytiälä, $\Delta^{3}$-carene was the main compound emitted by Scots pine throughout the study period. The observed and modelled $\Delta^{3}$-carene emissions for the spring, early and late summer and autumn measurement periods are presented in Figs. $3 a$ and $b$. Even though the seasonal emissions are rather well predicted by the model based on the simple temperature algorithm (statistics in Table 1), there is some discrepancy, especially in spring. The high emissions of 25 March, in particular, are not captured by the model. As pointed out above, light dependent monoterpene emissions have been found by several authors (e.g. Hansen and Seufert, 2003; Shao et al., 2001; Schuh et al., 1997; Staudt et al., 1997; Steinbrecher and Hauff, 1996; Steinbrecher et al., 1999; Seufert et al., 1997; Komenda et al., 1999). We therefore also applied the light and temperature dependent emission model (Eq. 4) to the $\Delta^{3}$-carene data of 25 March. The results are shown in Fig. 4, together with the predictions of the average seasonally fitted temperature algorithm, and a dedicated temperature algorithm fitted to the data of 25 March only. The light and temperature dependent algorithm (denoted " $\mathrm{T}, \mathrm{L}$ " in the figure) captures the daily emission cycle rather well $\left(\mathrm{R}^{2}\right.$ of 0.89$)$, whereas the dedicated temperature algorithm ( $\mathrm{T}(25 / 03 / 2003))$ underpredicts the morning and noontime emissions and overpredicts the afternoon and early evening emissions. However, the standard emission potential given by the dedicated temperature algorithm is too large to be realistic, and the corresponding $\beta$ coefficient is also very high. The average spring algorithm (T(spring 2003)), on the other hand, is only able to produce one third of the observed daily maximum emission while also overpredicting the late afternoon emissions.

In search for an explanation for this type of sudden emission bursts in spring one could argue that while monoterpenes are usually emitted from storage pools, the pools might be empty after winter, and when the plant starts to synthesize monoterpenes the emission might at first occur in concert with the light dependent production. Then as the season progresses and the pools start to fill, the emission becomes saturated and assumes the more stable temperature dependent pattern. However, our present data is too limited to deduce the origin of this irregular emission behaviour.

Even though the emission burst of 25 March remains unexplained, these results suggest that there may be several different processes which all contribute to the $\Delta^{3}$-carene emissions of Scots pine. As there were also other irregularities in the modelled monoterpene emissions when compared to the observations, such processes may apparently be active or inactive at different times during the growing season, bringing an added uncertainty to e.g. regional emission models where annual, seasonal, or other average standard emission potentials are used.

\section{Conclusions}

In conclusion we can say that a clear seasonal cycle has been established for the monoterpene emissions of Scots pine growing in a boreal forest environment. The emission rates are very high in spring, somewhat lower in early summer and high again in late summer, with a gradual decrease in autumn. The spectrum of the emitted compounds also varies during the course of the growing season; the very reactive sesquiterpenes and $\mathrm{MBO}$, for instance, are emitted in quantity only during part of the growing season. It is obvious 
that these seasonal and spectral variations must be taken into consideration when constructing emission inventories to be used in e.g. atmospheric chemistry modeling in the boreal environment.

According to our results, the simple temperature dependent emission algorithm and seasonal emission potentials can be applied to adequately predict the emission rates of most of the compounds emitted by Scots pine. However, our results also suggest that especially during the spring recovery period of the vegetation there may be several different processes contributing to the monoterpene emissions of Scots pine, and that such processes may also be active or inactive at other times during the growing season. Thus, further measurements, preferably combined with plant physiological data and/or modelling are needed to resolve the details of the emission processes on those occasions.

When standardized to $25^{\circ} \mathrm{C}$, the average noontime monoterpene emission rate in our study is $1.16 \mu \mathrm{g} \mathrm{g}^{-1} \mathrm{~h}^{-1}$, which is in accordance with earlier measurements of Scots pine. Komenda and Koppmann (2002) measured standardized emission rates between $0.06-0.64 \mu \mathrm{g} \mathrm{g}^{-1} \mathrm{~h}^{-1}$ for young pines and $0.24-3.7 \mu \mathrm{g} \mathrm{g}^{-1} \mathrm{~h}^{-1}$ for mature pines. Janson (1993) has also reported values quite close to our measurements $\left(0.8 \mu \mathrm{gg}^{-1} \mathrm{~h}^{-1}\right)$. The seasonal behaviour of the standard emission potential in our study, with high emission potentials in spring and early summer, lower in late summer and higher again towards autumn, is also in accordance of the seasonal behaviour observed in other similar studies (Janson, 1993; Komenda and Koppmann, 2002). The average $\beta$ coefficient value obtained in Hyytiälä is 0.10 , which is very close to the empirical value of 0.09 usually applied in biogenic emission modelling studies (Guenther et al., 1993; Guenther, 1997).

The darkened enclosure experiments did not resolve the issue of temperature and light dependence of 1,8-cineole and MBO. Based on the experiments and the nonlinear regression analysis of the measured emission rates, however, we can tentatively identify Scots pine as a light and temperature dependent 1,8-cineole emitter. The light and temperature dependence of MBO emissions found in some studies (e.g. Harley et al., 1998), on the other hand, can not be confirmed, as the light and temperature dependent algorithm failed during all seasons, while the temperature dependent algorithm captured the emission pattern fairly well in summer. In order to properly assess the dependencies and the standard emission potentials of these compounds further measurements are needed, especially in late summer when the emissions are highest.

According to our results, Scots pine emits sesquiterpenes only during the summer months. Thus it is not likely that they could cause the new particle formation events observed in Hyytiälä during spring (Kulmala et al., 2001) - however, their oxidation products can participate in the growth processes of the newly formed particles later in the summer.
Edited by: A. Laaksonen

\section{References}

Bonn, B. and Moortgat, G. K.: Sesquiterpene ozonolysis: origin of atmospheric new particle formation from biogenic hydrocarbons, Geophys. Res. Lett., 30, 1585, doi:10.1029/2003GL017000, 2003.

Boy, M. and Kulmala, M.: Nucleation events in the continental boundary layer; Influence of physical and meteorological parameters, Atmos. Chem. Phys., 2, 1-16, 2002,

SRef-ID: 1680-7324/acp/2002-2-1.

Ciccioli, P., Fabozzi, C., Brancaleoni, E., Cecinato, A., Frattoni, M., Bode, K., Torres, L., and Fugit, J.-L.: Use of isoprene algorithm for predicting the monoterpene emission from Mediterranean holm oak Quercus Ilex L: performance and limits of this approach, J. Geophys. Res., 102, 23 319-23 328, 1997.

Finlayson-Pitts, B. J. and Pitts Jr., J. N.: Chemistry of the upper and lower atmosphere, Academic Press, San Diego, California, 969, 2000.

Goldan, P. D., Kuster, W. C., and Fehsenfeld, F. C.: The observation of a C5 alcohol emission in a North American pine forest, Geophys. Res. Lett., 20, 1039-1042, 1993.

Guenther, A., Zimmerman, P. R., Harley, P. C., Monson, R. K., and Fall, R.: Isoprene and monoterpene emission rate variability: Model evaluations and sensitivity analyses, J. Geophys. Res., 98, 12 609-12 617, 1993.

Guenther, A.: Seasonal and spatial variations in natural volatile organic compound emissions, Ecol. Appl., 7(1), 34-45, 1997.

Hakola, H., Laurila, T., Rinne, J., and Puhto, K.: The ambient concentrations of biogenic hydrocarbons at a Northern European, boreal site, Atmos. Environ., 34, 4971-4982, 2000.

Hakola, H., Tarvainen, V., Laurila, T., Hiltunen, V., Hellén, H., and Keronen, P.: Seasonal variation of VOC concentrations above a boreal coniferous forest, Atmos. Environ., 37, 1623-1634, 2003.

Hansen, U. and Seufert, G.: Temperature and light dependence of $\beta$-caryophyllene emission rates, J. Geophys. Res., 108(D24), 4801, doi:10.1029/2003JD003853, 2003.

Harley, P., Fridd-Stroud, V., Greenberg, J., Guenther, A., and Vasconcellos, P.: Emission of 2-methyl-3-buten-2-ol by pines: A potentially large natural source or reactive carbon to the atmosphere, J. Geophys. Res., 103(D19), 25 479-25 486, 1998.

Hauff, K., Rössler, J., Hakola, H., and Steinbrecher, R.: Isoprenoid emission in European Boreal forests, in: Proc. of EUROTRAC Symposium '98, edited by: Borrell, P. M. and Borrell, P., WIT Press, Southampton, 97-102, 1999.

Hiltunen, R.: Genetic variation and interrelationships of the cortical monoterpenes, foliar mineral elements, and growth characteristics of eastern white pine, Diss., Michigan State University, USA, 1968.

Hoffmann, T., Odum, J. R., Bowman, F., Collins, D., Klockow, D., Flagan, R. C., and Seinfeld, J. H.: Formation of organic aerosols from the oxidation of biogenic hydrocarbons, J. Atmos. Chem., 26, 189-222, 1997.

Jaoui, M., Leungsakul, S., and Kamens, R. M.: Gas and particle products distribution from the reaction of $\beta$-caryophyllene with ozone, J. Atmos. Chem., 45, 261-287, 2003.

Janson, R.: Monoterpene emissions from Scots Pine and Norwegian Spruce, J. Geophys. Res., 98, 2839-2850, 1993. 
Janson, R. and De Serves, C.: Acetone and monoterpene emissions from the boreal forest in northern Europe, Atmos. Environ., 35, 4629-4637, 2001.

Janson, R., Rosman, K., Karlsson, A., and Hansson, H.-C.: Biogenic emissions and gaseous precursors to forest aerosols, Tellus B, 53, 423-440, 2001.

Komenda, M., Koppmann, R., von Czapiewski, K., and Wildt, J.: Emissions of volatile organic compounds from pines (Pinus sylvestris): a comparison of laboratory and field studies, P1.30, Book of Abstracts of the Sixth Scientific Conference of the International Global Atmospheric Chemistry Project (IGAC), Bologna, Italy, September 13-17, 44, 1999.

Komenda, M. and Koppmann, R.: Monoterpene emissions from Scots pine (Pinus sylvestris): Field studies of emission rate variabilities, J. Geophys. Res., 107, D13, doi:10.1029/2001JD000691, 2002.

Kulmala, M., Pirjola, L., and Mäkelä, J. M.: Stable sulphate clusters as a source of new atmospheric particles, Nature, 404, 66-69, 2000.

Kulmala, M., Hämeri, K., Aalto, P. P., Mäkelä, J. M., Pirjola, L., Nilsson, E. D., Buzorius, G., Rannik, Ü., Dal Maso, M., Seidl, W., Hoffmann, T., Janson, R., Hansson, H. C., Viisanen, Y., Laaksonen, A., and O'Dowd, C. D.: Overview of the international project on biogenic aerosol formation in the boreal forest (BIOFOR), Tellus B, 53, 324-343, 2001.

Kulmala, M., Vehkamäki, H., Petäjä, T., Dal Maso, M., Lauri, A., Kerminen, V.-M., Birmili, W., and McMurry, P. H.: Formation and growth rates of ultrafine atmospheric particles: A review of observations, J. Aerosol Sci., 35, 143-176, 2004.

Kurpius, M. R. and Goldstein, A. H.: Gas-phase chemistry dominates $\mathrm{O} 3$ loss to a forest, implying a source of aerosols and hydroxyl radicals to the atmosphere, Geophys. Res. Lett., 30, 1371, doi:10.1029/2002GL016785, 2003.

Lamb, B., Westberg, H., Allwine, E., and Quarles, T.: Biogenic hydrocarbon emissions from deciduous and coniferous species in the US, J. Geophys. Res., 90, 2380-2390, 1985.

Lindfors, V. and Laurila, T.: Biogenic volatile organic compound (VOC) emissions from forests in Finland, Boreal Environ. Res., 5, 95-113, 2000.

Lindfors, V., Laurila, T., Hakola, H., Steinbrecher, R., and Rinne, J.: Modeling speciated terpenoid emissions from the European boreal forest, Atmos. Environ., 34, 4983-4996, 2000.

Monson, R. K., Lerdau, M. T., Sharkey, T. D., Schimel, D. S., and Fall, R.: Biological aspects of constructing volatile organic compound emission inventories, Atmos. Environ., 29(21), 29833002,1995
Mäkelä, J. M., Aalto, P., Jokinen, V., Pohja, T., Nissinen, A., Palmroth, S., Markkanen, T., Seitsonen, K., Lihavainen, H., and Kulmala, M.: Observation of ultrafine aerosol particle formation and growth in boreal forest, Geophys. Res. Lett., 24, 1219-1222, 1997.

Niinemets, Ü. and Reichstein, M.: Controls on the emission of plant volatiles through stomata: Different sensitivity of emission rates to stomatal closure explained, J. Geophys. Res., 108(D7), 4208, doi:10.1029/2002JD002620, 2003.

Rinne, J., Hakola, H., and Laurila, T.: Vertical fluxes of monoterpenes above a Scots pine stand in the boreal vegetation zone, Phys. Chem. Earth (B), 24, 711-715, 1999.

Rinne, J., Hakola, H., Laurila, T., and Rannik, Ü.: Canopy scale monoterpene emissions of Pinus sylvestris dominated forests, Atmos. Environ., 34, 1099-1107, 2000.

Schuh, G., Heiden, A. C., Hoffmann, Th., Kahl, J., Rockel, P., Rudolph, J., and Wildt, J.: Emissions of volatile organic compounds from sunflower and beech: dependence on temperature and light intensity, J. Atmos. Chem., 27, 291-318, 1997.

Seufert, G., Bartzis, J., Bomboi, T., Ciccioli, P., Cieslik, S., Dlugi, R., Foster, P., Hewitt, C. N., Kesselmeier, J., Kotzias, D., Lenz, R., Manes, F., Perez-Pastor, R., Steinbrecher, R., Torres, L., Valentini, R., and Versino, B.: The BEMA-project: an overview of the Casterporziano experiments, Atmos. Environ., 31 (SI), 5 18, 1997.

Shao, M., Czapiewski, K. V., Heiden, A. C., Kobel, K., Komenda, M., Koppmann, R., and Wildt, J.: Volatile organic compound emissions from Scots pine: Mechanisms and description by algorithms, J. Geophys. Res., 106(D17), 20 483-20 492, 2001.

Staudt, M., Bertin, N., Hanse, U., Seufert, G., Ciccioli, P., Foster, P., Frenzel, B., and Fugit, J.-L.: Seasonal and diurnal patterns of monoterpene emissions from Pinus pinea (L.) under field conditions, Atmos. Environ., 32, 145-156, 1997.

Staudt, M., Bertin, N., Frenzel, B., and Seufert, G.: Seasonal variation in amount and composition of monoterpenes emitted by young Pinus pinea trees - Implications for emission modelling, J. Atmos. Chem., 35, 77-99, 2000.

Steinbrecher, R. and Hauff, K.: Isoprene and monoterpene emission from Mediterranean oaks, in: Proc. of EUROTRAC Symposium '96, edited by: Borrell, P. M., Borrell, P., Kelly, K., Cvitaš, T., and Seiler, W., Computational Mechanics Publications, Southampton, 229-233, 1996.

Steinbrecher, R., Hauff, K., Hakola, H., and Rössler, J.: A revised parameterization for emission modeling of isoprenoids for Boreal plants, in: Biogenic VOC Emissions and Photochemistry in the Boreal Regions of Europe - Biphorep, edited by: Laurila, T. and Lindfors, V., Air Pollution Research Report No. 70, Commission of the European Communities, Luxembourg, 2943, 1999. 